\title{
HUBUNGAN ANTARA DUKUNGAN SOSIAL DENGAN RESILIENSI PADA NARAPIDANA PIDANA UMUM DI LAPAS KLAS II A AMBARAWA
}

\author{
Laela Nur Istiqomah ${ }^{1}$, Margaretta Erna Setjaningrum ${ }^{2}$ \\ email: lalaela92@yahoo.com ${ }^{l}$ \\ Universitas Kristen Satya Wacana ${ }^{1,2}$
}

\begin{abstract}
This aim of this study was to find out whether there is a relationship between social support and resilience of general criminal prisoners at Class II A Correctional Institution Ambarawa. Resilience means that the ability of individuals to adapt the difficulties which they faced, so that they can remain calm and rise from the difficulties. The subject of this study is general criminal prisoners who are in the early adult stage (18-40 years) and has served a half sentence. The data is taken by using quantitative methods with purposive sampling technique. Based on this result of the study has found that the correlation coefficient $(r)=0,269 ; p<0.05$ with the effect of social support for resilience of 7,23\% and $92,77 \%$ is influenced by other factors. This study concludes that there is a significant positive relationship between social support and resilience to general criminal prisoners at Class II A Correctional Institutions Ambarawa.
\end{abstract}

Key Words : Social Support, Resilience

Abstrak
Penelitian ini bertujuan untuk mengetahui ada atau tidaknya hubungan dukungan sosial dengan resiliensi pada narapidana pidana umum di Lapas Klas II A Ambarawa. Resiliensi yang dimaksud adalah kemampuan individu untuk dapat beradaptasi dalam kesulitan yang dihadapi, sehingga dapat bersikap tenang dan bangkit dari kesulitan yang dihadapi. Subyek penelitian ini adalah narapidana pidana umum yang berada pada tahap masa dewasa awal (18-40 tahun) dan sudah menjalani setengah masa pidana. Data diambil dengan menggunakan metode kuantitatif dengan teknik purposive sampling. Berdasarkan hasil penelitian didapatkan hasil koefisien korelasi $(r)=0,269 ; \mathrm{p}<0.05$ dengan pengaruh dukungan sosial terhadap resiliensi sebesar 7,23\% dan sebesar $92,77 \%$ dipengaruhui oleh faktor lain. Penelitian ini menyimpulkan bahwa terdapat hubungan positif yang signifikan antara dukungan sosial dengan resiliensi pada narapidana pidana umum di Lapas Klas II A Ambarawa.

Kata Kunci : Dukungan Sosial, Resiliensi

\section{PENDAHULUAN}

Lapas Klas II A Ambarawa memiliki sebanyak 510 Warga Binaan Pemasyarakatan atau yang sering disebut dengan WBP, WBP di Lembaga Pemasyarakatan Klass II A Ambarawa dikhususkan hanya untuk narapidana laki-laki dengan berbagai macam pidana dan seiring berjalannya waktu jumlah WBP bisa berkurang atau bahkan bertambah berdasarkan lamanya masa pidana pada masing-masing narapidana. Seluruh kegiatan WBP Lapas (Lembaga
Pemasyarakatan) Klas II A Ambarawa sudah terjadwal dengan rapi setiap harinya. Dalam Lapas Ambarawa pun memiliki aturan-aturan yang ketat untuk para WBP yang membatasi kegiatan narapidana, seperti berkumpul dengan keluarga atau kerabat, konsumsi makanan, atau bahkan bebas untuk dapat menghirup udara segar mengingat bahwa hanya di waktu tertentu saja WBP dapat menikmati udara segar. Dengan hal tersebut banyakanya narapidana yang kesulitan untuk dapat beradaptasi dengan 
kegiatan maupun aturan di dalam Lembaga Klas II A Ambarawa. Kadang kala narapidana memilih untuk berdiam diri di kamar dan tidak mengikuti kegiatan yang ada dikarenakan mereka mulai jenuh akan rutinitas yang sama setiap harinya.

Berdasarkan sharing peneliti dengan beberapa narapidana di Lembaga Pemasyarakatan Klas II A Ambarawa pada tanggal 2 Febuari 2019, ditemukan bahwa, narapidana yang awalnya dapat hidup bebas dan berkumpul dengan keluarga maupun kerabat, dapat melakukan kegiatan yang mereka mau, mendapatkan keinginan mereka, namun sekarang mereka memiliki rutinitas kegiatan yang sudah terjadwal dan segala kegiatannya di atur oleh aturan dari LP. Hal tersebut membuat para WBP kesulitan untuk dapat bertahan maupun beradaptasi di dalam LP.

Hal tersebut menimbulkan beberapa pertanyaan apakah dengan adanya dukungan sosial yang diberikan oleh keluarga, teman ataupun sahabat, dan orang yang dianggap penting oleh narapidana dapat membentuk resiliensi yang tinggi di dalam diri narapidana tersebut.

Berdasarkan latar belakang yang telah ada, maka yang menjadi rumusan permasalahan adalah apakah ada hubungan positif antara dukungan sosial dengan resiliensi pada narapidana dengan kasus pidana umum di Lembaga Pemasyarakatan Klass II A Ambarawa. Tujuan dari dilakukannya penelitian ini adalah untuk menguji hubungan positif antara dukungan sosial dengan resiliensi terhadap narapidana dengan kasus pidana umum di Lembaga Pemasyarakatan Klass II A Ambarawa.

\section{KAJIAN PUSTAKA}

Zimet (1998) menyatakan, dukungan sosial merupakan dukungan yang bersumber dari keluarga, teman, dan orang yang dianggapoleh individu tersebut. Hal senada juga diungkapkan oleh Sarafino (1994) bahwa dukungan sosial mengacu pada memberikan kenyamanan pada orang lain, merawatnya atau menghargainya. Zimet, menyatakan bahwa terdapat tiga aspek dukungan sosial, di antaranya: keluarga, teman dan orang penting.

Dalam kehidupan bermasyarakat sangat diperlukannya dukungan sosial karena manusia diciptakan sebagai makhluk sosial, arti sosial mengacu pada penerimaan rasa aman, peduli, penghargaan, atau bantuan yang diterima seseorang dari orang lain maupun kelompok (Mufidah, 2017). Menurut 
Bull (2006) dalam Raisa dan Ediati (2017), dukungan sosial pada narapidana dapat mengurangi dampak psikologis dari proses penahanan, misalnya mengurangi dampak stres dan kesepian, serta menghindari dari tindakan menyakiti diri atau bunuh diri. Dukungan sosial yang didapatkan narapidana dapat berasal dari keluarga, teman, pasangan, petugas lembaga pemasyarakatan, psikolog, pemuka agama, dan sesama narapidana.

Resiliensi adalah suatu kemampuan yang dimiliki oleh individu untuk dapat beradaptasi dengan baik meskipun dihadapkan dengan keadaan yang sulit ( Stein, 2005). Sedangkan menurut Connor dan Davidson (2003), resiliensi adalah kemampuan individu untuk dapat beradaptasi dalam kesulitan yang dihadapi, sehingga dapat bersikap tenang dan bangkit dari kesulitan yang dihadapi serta menemukan kembali semangat, kekuatan, dan tujuan yang realistik. Penelitian yang dilakukan oleh Riza dan Herdiana (2013), menggambarkan subyek yang memiliki resiliensi tinggi memiliki rencana yang akan dilakukan setelah keluar dari penjara. Rencana tersebut tentunya bagaimana narapidana tersebut dapat memulai hidup baru. Hidup untuk membahagiakan keluarga yang selalu mendukungnya walaupun dirinya ada di penjara. Dengan demikian, narapidana mampu menjalankan segala aktivitas tanpa terbebani dengan segala kegiatan selama berada di Lembaga Pemasyarakatan.

Dalam penelitian Raisa dan Ediati (2016) tentang "Hubungan antara dukungan sosial dengan resiliensi pada narapidana di Lembaga Pemasyarakatan Kelas IIA Wanita Semarang”, terdapat hubungan positif antara dukungan sosial dengan resiliensi, dukungan yang dirasakan oleh narapidana dapat meningkatkan resiliensi yang dimiliki. Sedangkan dalam penelitian Diaz (2012) tentang "Hubungan antara Dukungan Sosial dan Resiliensi pada Remaja Penyandang Cacat Fisik", tidak terdapat hubungan yang signifikan antara dukungan sosial dengan resiliensi

\section{METODE PENELITIAN}

Populasi dalam penelitian ini adalah narapidana laki-laki dengan kasus pidana umum di Lembaga Pemasyarakatan Klas II A Ambarawa berjumlah 314 narapidana. Partisipan dalam penelitian ini berjumlah 63 narapidana yang berada pada tahap masa dewasa awal (18-40 tahun) dan yang sudah menjalani setengah masa pidana. 
Teknik sampling yang digunakan adalah purposive sampling. Penelitian ini menggunakan metode kuantitatif dengan teknik pengumpulan data berupa skala psikologi, terdiri dari skala dukungan sosial yang berjumlah 24 aitem dan skala resiliensi yang berjumlah 48 aitem. Analisis data dengan teknik statistik yang digunakan dalam penelitian ini berupa program sofware Statistik pada komputer (IBM SPSS Statistic 23).

\section{HASIL DAN PEMBAHASAN}

\section{Analisis Deskriptif Dukungan Sosial}

Tabel 1 Kategori Skor Variabel Dukungan

Sosial

\begin{tabular}{|c|c|c|c|c|}
\hline Interval & $\begin{array}{c}\text { Kate- } \\
\text { gori }\end{array}$ & Frek & $\begin{array}{c}\text { Me- } \\
\text { an }\end{array}$ & $\begin{array}{l}\text { St- } \\
\text { Dev }\end{array}$ \\
\hline $\begin{array}{l}45,5 \leq \\
x \leq 56\end{array}$ & $\begin{array}{l}\text { Sangat } \\
\text { Tinggi }\end{array}$ & $\begin{array}{c}26 \\
(41,2 \\
6 \%)\end{array}$ & \multirow[t]{4}{*}{$\begin{array}{c}43 \\
3\end{array}$} & \multirow[t]{4}{*}{6,4} \\
\hline $\begin{array}{l}35 \leq x \\
<45,5\end{array}$ & Tinggi & $\begin{array}{c}32 \\
(50,7 \\
9 \%)\end{array}$ & & \\
\hline $\begin{array}{l}24,5 \leq \\
x<35\end{array}$ & Rendah & $\begin{array}{c}5 \\
(7,93 \\
\%)\end{array}$ & & \\
\hline $\begin{array}{l}14 \leq x \\
<24,5\end{array}$ & $\begin{array}{l}\text { Sangat } \\
\text { Rendah }\end{array}$ & $\begin{array}{c}0 \\
(0 \%)\end{array}$ & & \\
\hline
\end{tabular}

Pada table 1 kategori skor variabel dukungan sosial dengan jumlah 63 subyek menunjukkan sebanyak 26 $(41,26 \%)$ narapidana menempati kategori "Sangat Tinggi", sebanyak 32 $(50,79 \%)$ narapidana menempati kategori "Tinggi", dan sebanyak 5 $(7,93 \%)$ narapidana menempati kategori "Rendah". Berdasarkan tabel di atas juga dapat dilihat bahwa mean sebesar 4,3 dan standar deviasi sebesar 6,4.

\section{Resiliensi}

Tabel 2 Kategori Skor Variabel Resiliensi

\begin{tabular}{|c|c|c|c|c|}
\hline Interval & $\begin{array}{l}\text { Kate- } \\
\text { gori }\end{array}$ & Frek & $\begin{array}{c}\text { Me- } \\
\text { an }\end{array}$ & $\begin{array}{l}\text { St- } \\
\text { Dev }\end{array}$ \\
\hline $\begin{array}{l}94,25 \leq \\
x \leq 116\end{array}$ & $\begin{array}{l}\text { Sangat } \\
\text { Tinggi }\end{array}$ & $\begin{array}{c}40 \\
(63,4 \\
9 \%)\end{array}$ & \multirow[t]{4}{*}{$\begin{array}{l}95 \\
36\end{array}$} & \multirow[t]{4}{*}{$\begin{array}{c}8,5 \\
6\end{array}$} \\
\hline $\begin{array}{r}72,5 \leq \\
x \\
<94,25\end{array}$ & Tinggi & $\begin{array}{c}23 \\
(36,5 \\
\%)\end{array}$ & & \\
\hline $\begin{array}{l}50,75 \leq \\
\mathrm{x}<72,5\end{array}$ & Rendah & $\begin{array}{c}0 \\
(0 \%)\end{array}$ & & \\
\hline $\begin{array}{l}29 \leq x \\
<50,75\end{array}$ & $\begin{array}{l}\text { Sangat } \\
\text { Rendah }\end{array}$ & $\begin{array}{c}\mathrm{O} \\
(\mathrm{O} \%)\end{array}$ & & \\
\hline
\end{tabular}

Pada table 2 kategori skor variabel dukungan sosial dengan jumlah 63 subyek menunjukkan sebanyak 40 $(63,49 \%)$ narapidana menempati kategori "Sangat Tinggi", dan sebanyak $23(36,5 \%)$ narapidana menempati kategori "Tinggi". Berdasarkan tabel di atas juga dapat dilihat bahwa mean sebesar 95,36 dan standar deviasi sebesar 8,56.

\section{Uji Normalitas}

Tabel 3. Normalitas Skala Dukungan Sosial dan Resiliensi

\begin{tabular}{|c|c|c|c|}
\hline & & $\begin{array}{c}\text { Dukungan } \\
\text { Sosial }\end{array}$ & Resiliensi \\
\hline N & & 63 & 63 \\
\hline \multirow{2}{*}{$\begin{array}{l}\text { Normal } \\
\text { Parameters }\end{array}$} & Mean & 43.30 & 95.37 \\
\hline & $\begin{array}{l}\text { Std. } \\
\text { Deviation }\end{array}$ & 6.407 & 8.569 \\
\hline $\begin{array}{l}\text { Most } \\
\text { Extreme }\end{array}$ & Absolute & .137 & .093 \\
\hline Differences & Positive & .076 & .053 \\
\hline & Negative & -.137 & -.093 \\
\hline $\begin{array}{l}\text { Kolmogorov- } \\
\text { Smirnov Z }\end{array}$ & & 1.091 & .737 \\
\hline $\begin{array}{l}\text { Asymp. } \\
\text { Sig. (2-tailed) }\end{array}$ & & .185 & .649 \\
\hline
\end{tabular}


Hasil perhitungan uji Kolmogorov-smirnov $Z$ pada resiliensi diperoleh besar nilai K-S-Z sebesar 0,737 dengan nilai sig $0,649(\mathrm{p}>0,05)$ dan pada dukungan sosial besar nilai $\mathrm{K}$ S-Z sebesar 1,091 dengan nilai sig 0,185 $(\mathrm{p}>0,05)$. Dari data tersebut artinya kedua variabel berdistribusi normal.

\section{Uji Linearitas}

Tabel 4. Linearitas Skala Dukungan Sosial dan Resiliensi

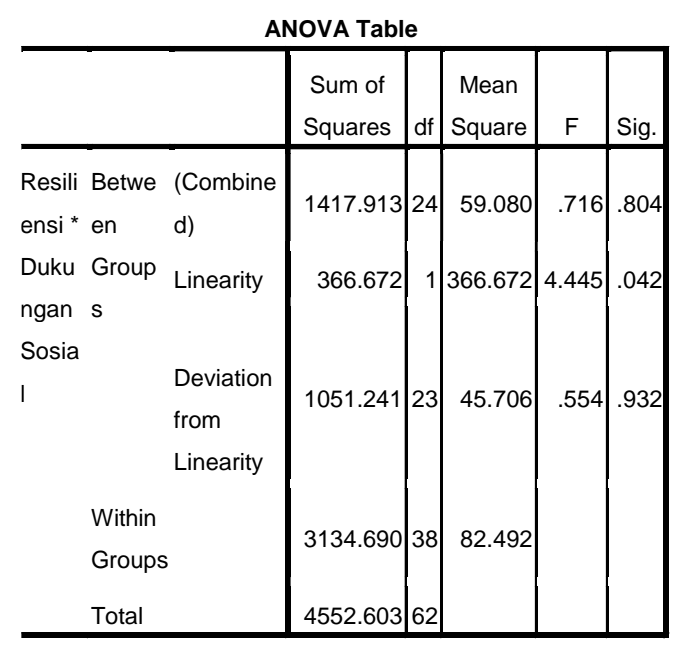

Berdasarkan hasil pengujian yang telah dilakukan, menunjukkan nilai Deviation from Linearity sebesar 0,932 ( $\mathrm{p}>0,05)$, artinya bahwa hubungan antara dukungan sosial dan resiliensi menunjukkan garis yang sejajar atau linier.

\section{Uji Korelasi}

Berdasarkan uji asumsi yang telah dilakukan, diketahui bahwa data berdistribusi normal dan kedua variabel penelitian linier, sehingga uji korelasi yang digunakan dalam penelitian ini adalah Spearman's Rho.

Tabel 5. Korelasi anatar Dukungan Sosial dengan Resiliensi

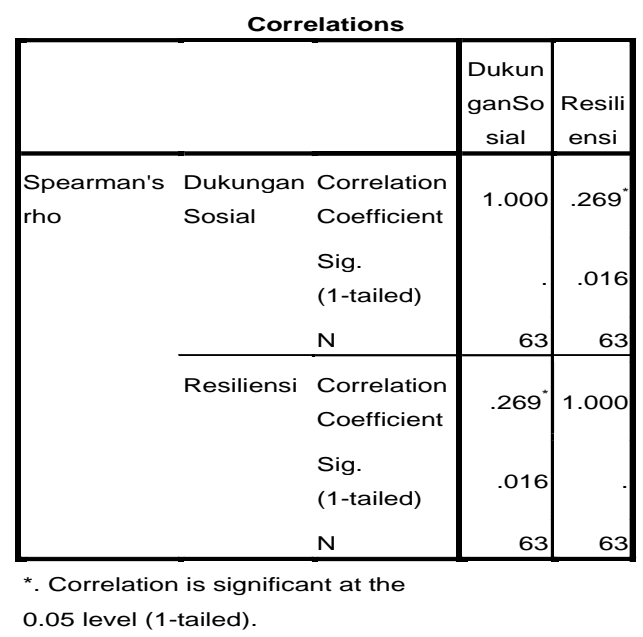

\section{Pembahasan}

Hasil dari penelitian menunjukkan hasil $r=0,269$ dan $\operatorname{sign}=0,016$ $(\mathrm{p}<0,05)$. Hasil tersebut menandakan bahwa hipotesis penelitian diterima. Adanya hubungan positif yang signifikan antara kedua variabel dapat diartikan sebagai semakin tinggi dukungan sosial yang diterima oleh narapidana maka akan semakin tinggi pula tingkat resiliensi yang dimiliki oleh narapidana, sebaliknya jika dukungan sosial yang diterima narapidana rendah maka tingkat resiliensi yang dimiliki oleh narapidana semakin rendah.

Berdasarkan penelitian yang telah dilakukan, menggambaran bahwa semakin tinggi dukungan yang diberikan oleh keluarga, teman, dan orang yang 
dianggap penting oleh narapidana akan membantu narapidana tersebut memiliki tingkat resiliensi yang tinggi pula, namun sebaliknya jika dukungan yang diberikan rendah maka akan sulitnya terbentuk resiliensi di dalam diri para narapidana atau rendahnya resiliensi yang dimilikinya. Narapidana dengan tingkat resiliensi yang tinggi memiliki kemampuan mudah beradaptasi dengan lingkungan, dapat mengendalikan diri, dan memandang kondisi yang dialami secara positif. Namun sebaliknya, jika narapidana dengan tingkat resiliensi yang rendah akan mengalami kesulitan dalam beradaptasi, tidak mampu mengendalikan emosi, dan memandang kondisi yang sedang dialaminya secara negatif (Riza dan Herdiana, 2013).

Berdasarkan uraian yang telah dipaparkan, dapat disimpulkan bahwa dukungan sosial yang dirasakan oleh narapidana di Lembaga Pemasyarakatan Klas II A Ambarawa dapat meningkatkan resiliensi yang dimiliki. Narapidana yang tidak mampu untuk mengatasi masalah dan merasa kesulitan dalam menjalani masa hukuman akan memiliki tingkat resiliensi yang rendah. Narapidana dengan tingkat resiliensi yang rendah diakibatkan oleh kurangnya dukungan yang diberikan, baik dari keluarga, teman, maupun orang yang dianggap penting oleh narapidana tersebut.

Hasil kategorisasi pada subyek penelitian menunjukan bahwa sebagian besar tingkat dukungan sosial yang diterima oleh narapidana berada pada kriteria tinggi yaitu sebanyak 32 narapidana $(50,79 \%)$, sedangkan pada resiliensi berada pada kriteria sangat tinggi yaitu sebanyak 40 narapidana $(63,49$. Berdasarkan hasil kategorisasi tersebut dapat disimpulkan bahwa subyek pada penelitian ini menerima dukungan sosial yang tinggi. Dengan adanya dukungan sosial yang sangat tinggi dapat membantu narapidana untuk membentuk resiliensi dengan baik di dalam dirinya. Sumbangan efektif yang diberikan oleh dukungan sosial terhadap resiliensi adalah sebesar $7,23 \%$ dan 92,77\% dipengaruhi oleh faktor lain di luar penelitian.

\section{PENUTUP}

\section{Kesimpulan}

Adanya hubungan positif antara dukungan sosial dengan resiliensi pada narapidana pidana umum di Lembaga Pemasyarakatan Klas II A Ambarawa. Dengan pengaruh dukungan social terhadap resiliensi sebesar 7,23\%, dan 
sebesar $92,77 \%$ dipengaruhi oleh faktor lain.

\section{Saran}

Saran bagi narapidana. Mengikuti kegiatan ibadah yang sudah terjadwal di Lembaga Pemasyarakatan Klas II A Ambarawa. Ikut serta mendaftarkan diri untuk mengikuti sidang Tim Pengamat Pemasyarakatan (TPP), sehingga para narapidana dapat menghabiskan waktu sebagai tamping maupun kurve yang dapat membantu kegiatan petugas atau pegawai di setiap harinya. Menghabiskan waktu dengan melakukan kegiatan yang positif dan bermanfaat.

$$
\text { Saran bagi Lembaga }
$$

Pemasyarakatan Klas II A Ambarawa. Berdarkan hasil penelitian menunjukkan adanya hubungan positif antara dukungan sosial dengan resiliensi. Diharapkan untuk pihak Lembaga Pemasyarakatan Klas II A Ambarawa ikut serta dalam mendukung, mendengarkan keluh kesah, serta memberikan masukan positif untuk para narapidana, sehingga narapidana akan merasa bahwa masih adanya orang yang peduli dan mendukung narapidana tersebut untuk melakukan berbagai hal yang positif.

Saran bagi peneliti selanjutnya. Penelitian ini masih terbatas, karena hanya mendukung dukungan sosial dengan resiliensi. Dengan demikian, masih ada banyaknya variabel lain yang turut memberikan pengaruh terhadap resiliensi pada narapidana. Diharapkan untuk peneliti selanjutnya dapat menambahkan faktor-faktor lain yang dapat mempengaruhi resiliensi, yaitu: self-esteem, spirituality, dan positive emotion

\section{DAFTAR PUSTAKA}

Connor KM, Davidson JR. 2013. Development of a new resilience scale: The Connor-Davidson resilience scale (CDRISC). Depression and anxiety, 2003, 18(2),76-82. Diakses pada 10 Febuari 2018. Avaible from: https://onlinelibrary.wiley.com/doi /epdf/10.1002/da.10113.

Diaz FMPKB. 2012. Hubungan Antara Dukungan Sosial Dan Resiliensi Pada Remaja Penyandang Cacat Fisik. Doctoral Dissertation. Sanata Dharma University, 2012. Diakses pada 28 Januari 2018. Avaible from: http://repository.usd.ac.id/29196/.

Mufidah AC. 2018. Hubungan Antara Dukungan Sosial Terhadap Resiliensi Mahasiswa Bidikmisi Dengan Mediasi Efikasi Diri. Jurnal Sains Psikologi, 2017, 6(2), 69-75. Diakses pada 28 Januari 2018. Avaible From: http://journal2.um.ac.id/index.php/ JSPsi/index

Raisa R, Ediati A. 2017. Hubungan Antara Dukungan Sosial Dengan Resiliensi Pada Narapidana Di 
Lembaga Pemasyarakatan Kelas

IIa Wanita

Semarang. Empati, 2017, 5(3),537-

542. Diakses pada 14 Januari 2018. Avaible from: https://ejournal3.undip.ac.id/index. php/empati/article/view/15398.

Riza M, Herdiana I. 2013. Resiliensi pada narapidana laki-laki di lapas klas 1 Medaeng. $J$ Psikolog Kepribadian dan Sos, 2013, 2(01), 1-6. Diakses pada 28 Januari 2018. Avaible from: http://journal.unair.ac.id/filerPDF/j pksfbd660cc7a2full.pdf.

Sarafino, E. P. 1994. Health Psychology: Biopsychosocial and Interaction. United States of America: John Wiley \& Sons, Inc., 1994. Diakses pada 4 Januari 2018. Avaible from:https://researchonline.jcu.edu .au/27775/4/27775\%20Sarafino\%2 0et\%20al\%202008\%20Front\%20P ages.pdf.

Stein M. 2005. Resilience and Young People Leaving Care: Overcoming the odds. Research Report. Joseph Rowntree Foundation. New York. Diakses pada 28 Januari. Avaible from:

http://eprints.whiterose.ac.uk/7317 6/1/Document.pdf.

Zimet GD, Dahlem NW, Zimet S, \& Farley GK. 1988. The Multidimensional Scale Of Perceived Social Support,. Journal of personality assessment, 1988, 52(1), 30-41. Diakses pada 10 Febuari 2018. Avaible from: https://www.tandfonline.com/doi/a bs/10.1207/s15327752jpa5 
